\title{
Novitates Bruneienses, 2. A remarkable new species of Begonia sect. Petermannia (Begoniaceae) from Brunei Darussalam
}

\author{
Y.W. Low ${ }^{1}$, A.A. Joffre ${ }^{2} \&$ A.K. Muhammad Ariffin ${ }^{2}$ \\ ${ }^{1}$ Herbarium, Singapore Botanic Gardens, National Parks Board, \\ 1 Cluny Road, 259569 Singapore \\ low yeewwen@nparks.gov,sg \\ ${ }^{2}$ Brunei National Herbarium, Forestry Department, \\ Ministry of Industry and Primary Resources, Jalan Menteri Besar, \\ Berakas, BB3910 Brunei Darussalam
}

\begin{abstract}
Begonia jamilahana Y.W.Low, Joffre \& Ariffin is described and illustrated here as a new species based on a collection from Ladan Hills Forest Reserve, Tutong, Brunei Darussalam. This new taxon is closely related to $B$. conniegeriae S.Julia \& Kiew and $B$. papyraptera Sands, but differs in a suite of morphological characters. Begonia jamilahana is placed in Begonia section Petermannia, the largest of all the sections recognised.
\end{abstract}

Keywords. Begonia jamilahana, Begoniaceae, Borneo

\section{Introduction}

Begonia is a well-known genus, largely due to its popularity in horticulture. They are mostly cultivated for their attractive foliage, as well as showy flowers (Holttum \& Enoch, 1995; Tebbit, 2005). At present, there are about 1500 species distributed throughout the tropics, except in Australia, with many more taxa yet to be discovered as individual species are commonly known to be confined to very small geographical areas (Tebbit, 2005; Heywood et al., 2007; Hughes, 2008).

Merrill (1921), in his bibliographic enumeration, listed 26 species of Begonia for Borneo, most of which were endemic species with the exception of $B$. repens Blume. The checklist by Hughes (2008) enumerated 95 species for Borneo, all of which are strictly restricted to the island. For Brunei, Coode et al. (1996) recorded 16 species, namely, Begonia awongii Sands, B. bahakensis Sands, B. baramensis Merr., $B$. bruneiana Sands, $B$. chlorandra Sands, B. cyanescens Sands, B. eutricha Sands, $B$. fuscisetosa Sands, B. hexaptera Sands, B. laccophora Sands, B. leucochlora Sands, $B$. leucotricha Sands, B. papyraptera Sands, B. sibutensis Sands, B. stenogyna Sands and $B$. temburongensis Sands. Four subspecies were recognised for Begonia bruneiana, namely $B$. bruneiana subsp. bruneiana, $B$. bruneiana subsp. angustifolia Sands, $B$. bruneiana subsp. labiensis Sands and B. bruneiana subsp. retakensis Sands. All of the Brunei begonias were newly described by Sands (1996), with the exception of Begonia baramensis Merr. 
A recent collection from the Ladan Hills Forest Reserve reveals yet another novelty for Brunei from Begonia section Petermannia (Klotzsch) A.DC. as delimited by Doorenbos et al. (1998). It has the following defining characters of the section, namely (i) 2-tepaled male flowers, (ii) anthers with unilaterally positioned slits, (iii) 5-tepaled female flowers, (iv) inflorescence protogynous, with 1-2-flowered female inflorescences, (v) trilocular ovary with axile placentation and bilamellate placentae, and (vi) fruits with equal wings. The Ladan Hills novelty is closely related to Begonia papyraptera, but differs in having (i) a smooth and terete stem in live material, (ii) scantily scattered translucent hispid hairs on both sides of the leaf lamina, (iii) a mature upper leaf surface that is dark green with red markings on vein axil nodes nearer to the base of the leaf, (iv) a pale green lower leaf surface, and (v) base of capsule wings cuneate. In contrast, Begonia papyraptera has (i) a ribbed and angular stem in live material, (ii) a leaf lamina that is glabrous on both sides, (iii) a leaf upper surface that is plain dark green with conspicuous white spots, (iv) a maroon lower leaf surface, and (v) base of capsule wings rounded. Apart from Begonia papyraptera, the Ladan Hills taxon is also closely related to Begonia conniegeriae S.Julia \& Kiew, but differs in the characters enumerated in Table 1. Hence, the Ladan Hills taxon is described here as new.

\section{New species}

Begonia jamilahana Y.W.Low, Joffre \& Ariffin, sp. nov. (sect. Petermannia)

Similar to Begonia papyraptera Sands but differs in having a smooth and terete stem, leaf blade scantily covered with translucent hispid hairs on both sides, upper mature leaf surface dark green with red markings on vein axil nodes nearer to the base of the leaf, lower leaf surface pale green, and base of capsule wings cuneate. - TYPE: Brunei, Tutong District, Lamunin, Ladan Hills Forest Reserve, Compartment 1, 58 $\mathrm{m}, 4^{\circ} 42^{\prime} 16^{\prime} \mathrm{N} 114^{\circ} 44^{\prime} 12^{\prime \prime} \mathrm{E}$, lowland mixed dipterocarp forest on yellow sandy clay soils, steep slope, 15 Dec 2010, P. Azlan, A.K. Muhd. Ariffin, A. Watu \& M. Rauzaidi $B R U N 23373$ (holotype BRUN (including spirit material); isotypes K, SING). (Fig. 1, 2)

Cane-like begonia, c. $40 \mathrm{~cm}$ tall, most parts of the plant glabrous except for the upper and lower surface of lamina scantily covered with hispid translucent hairs neatly arranged in between veins. Stems pale green, $0.8-1.5 \mathrm{~cm}$ thick, very succulent, terete, internodes 2.5-9 cm long, laxly branched, nodes red, not swollen. Stipules dark red, narrowly lanceolate, c. 1-2 cm long, c. $0.3-0.5 \mathrm{~cm}$ wide at the base, keeled, margin entire, apex acute, caducous. Leaves alternate, oblique, distant, held horizontally; petioles light green with both ends red, 5-20.5 cm long, terete; lamina dark green with red markings on vein axil nodes nearer to the base of the leaf and iridescent above, pale green beneath, young leaves very rarely with small white spots above, fading in older leaves, asymmetric, elliptic to broadly elliptic, $12-19 \times 11.5-14 \mathrm{~cm}$, broad side $8-10.5$ 
cm wide, base cordate, basal lobes $3.5-7 \mathrm{~cm}$, margin dentate, apex acuminate, acumen 1.5-2 cm long; venation palmate-pinnate, 7-9 veins, each branching dichotomously 2-3 times, vein nodes red near junction of petiole and gradually fading to pale green towards the margin, flat and prominent on the upper surface, raised and prominent on the lower surface. Inflorescences terminal, protogynous; female inflorescences (1-)2-flowered, positioned one node below the male inflorescences or solitary, peduncles absent; male inflorescences composed up to 4 cymose partial inflorescences, each monochasium with 3-6 flowers, peduncles 7-15 mm long. Bracts dark red, ovate, keeled, c. 0.9-1.1 cm long, c. $0.8 \mathrm{~cm}$ wide, margin entire, persistent. Male flowers: pedicel white to pale pink, 7-9 mm long; tepals 2, pale pink with red flushes, ovateelliptic, 7-9 × 4-5 mm, margin entire, apex rounded; stamens c. 39, cluster conical, stalked; filaments c. $0.8 \mathrm{~mm}$ long; anthers yellow, oblong, c. $1 \mathrm{~mm}$ long, apex slightly emarginate. Female flowers: pedicel pale green, 4-6 mm long; ovary pale green, 1.3-2 $\times 0.3-0.4 \mathrm{~cm}$, wings 3 , equal, locules 3 , placentae 2 per locule, placentation axile; tepals 5, pink, outer 4 tepals ovate, c. $18-20 \times 8-11 \mathrm{~mm}$, innermost tepal oblanceolate, c. $10 \times 8 \mathrm{~mm}$, margin entire, apex rounded; styles 3, deeply Y-shaped, c. $6 \mathrm{~mm}$ long, divided c. $2 \mathrm{~mm}$ from the base; stigma yellow, papillose forming a continuous twisted band. Capsules (1-)2, pendent, 2.7-30 × 1.5-1.7 cm, pale green when young, brown when mature, locules 3 , wings 3 , equal, leathery when fresh, thinly fibrous when dry, slightly expanded, tip rounded, dehiscing between locule and wing; pedicel c. 4-6 mm long.

Additional specimens examined. BORNEO: Brunei: Tutong District, Lamunin, Ladan Hills Forest Reserve, Ladan Hill, 20 Nov 2014, A.A. Joffre et al. BRUN 24029 (BRUN, SING).

Distribution and habitat. Begonia jamilahana is so far known only from the Ladan Hills Forest Reserve, where it was documented on steep earth banks and adjacent slopes in the mixed dipterocarp forest on yellow sandy clay soils.

Etymology. This species is named for Hajah Jamilah binti Haji Abdul Jalil, acting Deputy Director of the Brunei Forestry Department, upon her retirement in 2015, as a token of appreciation for her excellent service rendered to the Forestry Department, as well as her unwavering support for the Brunei-Singapore botanical exploration programme.

Provisional IUCN conservation assessment. Begonia jamilahana is so far known only from a single population at Compartment 1, Ladan Hills Forest Reserve. The IUCN status proposed here is Least Concern (LC) as the species is protected in a forest reserve with no discernible threats. The Brunei Ministry of Industry and Primary Resources officially announced in 2014 that logging will be phased out in all forest reserves (Brunei Times, 2014).

Notes. Begonia papyraptera Sands was described in Coode et al. (1996), based on a single collection from the helipad Landing Point (LP) 286, Batu Apoi Forest Reserve, 
Table 1. Comparison of morphological characteristics, habitat and distribution among Begonia conniegeriae S.Julia \& Kiew, B. jamilahana Y.W.Low, Joffre \& Ariffin and B. papyraptera Sands.

\begin{tabular}{|c|c|c|c|}
\hline & Begonia conniegeriae & Begonia jamilahana & Begonia papyraptera \\
\hline $\begin{array}{l}\text { Stem (in life), } \\
\text { texture }\end{array}$ & Smooth and terete & Smooth and terete & Ribbed and angular \\
\hline $\begin{array}{l}\text { Stem (in life), } \\
\text { colour }\end{array}$ & Reddish or red brown & $\begin{array}{l}\text { Pale green with red } \\
\text { nodes }\end{array}$ & Pale green \\
\hline $\begin{array}{l}\text { Stem nodes (in } \\
\text { life), swollen }\end{array}$ & Yes & No & Yes \\
\hline $\begin{array}{l}\text { Upper lamina } \\
\text { surface, } \\
\text { pubescence }\end{array}$ & $\begin{array}{l}\text { Sparsely covered with } \\
\text { translucent erect hairs }\end{array}$ & $\begin{array}{l}\text { Scantily covered with } \\
\text { translucent erect hairs }\end{array}$ & Glabrous \\
\hline $\begin{array}{l}\text { Upper lamina } \\
\text { surface (in life), } \\
\text { colour and } \\
\text { markings }\end{array}$ & Dark green & $\begin{array}{l}\text { Dark green with red } \\
\text { markings on vein axil } \\
\text { nodes near the leaf } \\
\text { base }\end{array}$ & $\begin{array}{l}\text { Dark green with } \\
\text { white spots }\end{array}$ \\
\hline $\begin{array}{l}\text { Lower leaf } \\
\text { surface, } \\
\text { pubescence }\end{array}$ & $\begin{array}{l}\text { Sparsely covered with } \\
\text { translucent erect hairs }\end{array}$ & $\begin{array}{l}\text { Scantily covered with } \\
\text { translucent erect hairs }\end{array}$ & Glabrous \\
\hline $\begin{array}{l}\text { Lower leaf } \\
\text { surface (in life), } \\
\text { colour }\end{array}$ & Pale green & Pale green & Maroon \\
\hline $\begin{array}{l}\text { Capsule wings, } \\
\text { shape proportion }\end{array}$ & Unequal & Equal & Equal \\
\hline $\begin{array}{l}\text { Capsule wing } \\
\text { base, shape }\end{array}$ & Cuneate & Cuneate & Rounded \\
\hline Habitat, substrate & Limestone & $\begin{array}{l}\text { Yellow sandy clay } \\
\text { soils }\end{array}$ & Unknown \\
\hline Distribution & $\begin{array}{l}\text { Lobang Cina, Gunung } \\
\text { Mulu National Park, } \\
\text { Marudi District, } \\
\text { Sarawak, Malaysia }\end{array}$ & $\begin{array}{l}\text { Ladan Hills Forest } \\
\text { Reserve, Tutong } \\
\text { district, Brunei } \\
\text { Darussalam }\end{array}$ & $\begin{array}{l}\text { Batu Apoi Forest } \\
\text { Reserve, Temburong } \\
\text { district, Brunei } \\
\text { Darussalam }\end{array}$ \\
\hline
\end{tabular}




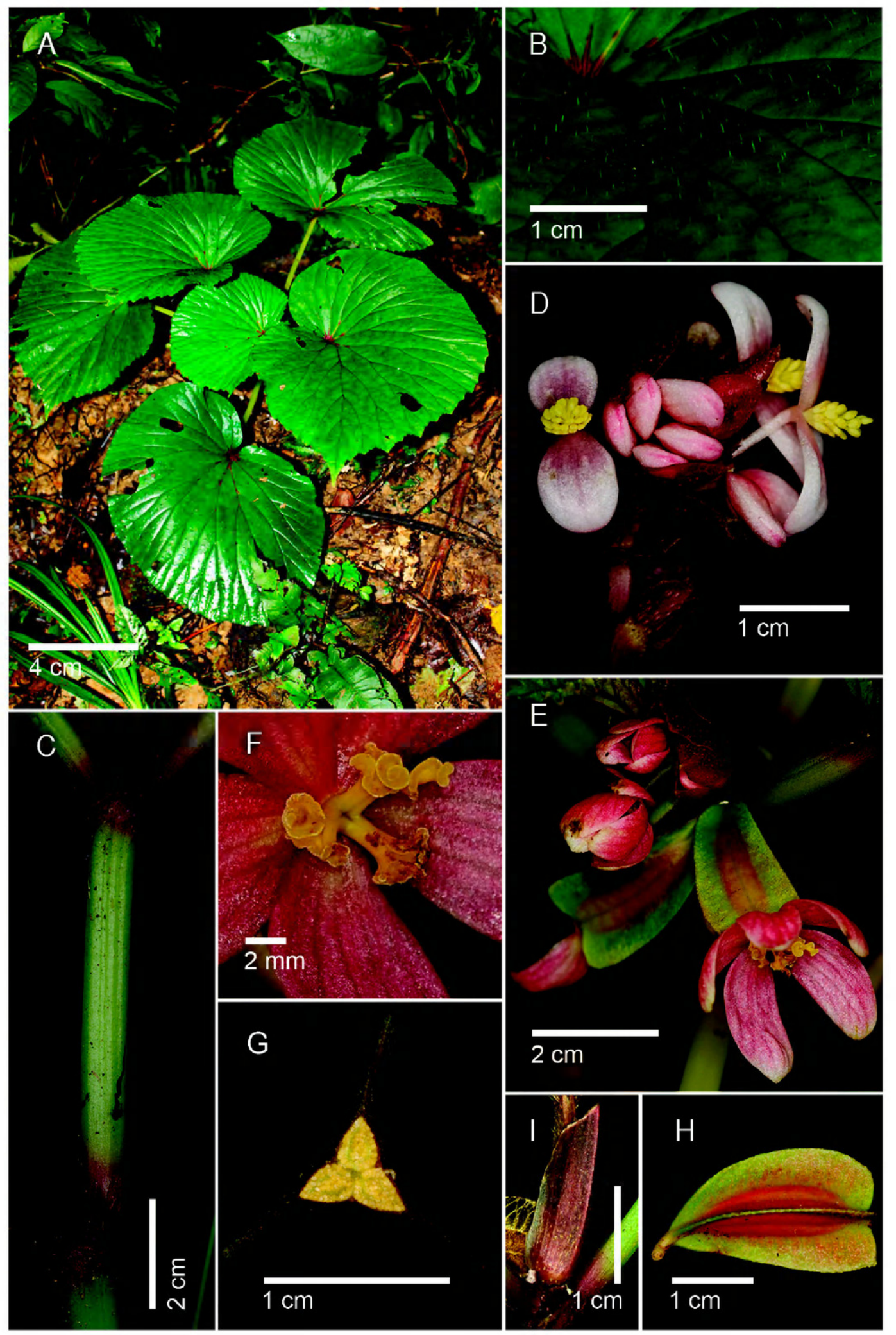

Fig. 1. Begonia jamilahana Y.W.Low, Joffre \& Ariffin. A. Habit. B. Close-up of upper leaf surface. C. Detail of stem showing red nodes. D. Close-up of male portion of inflorescence. E. Close-up of female flowers. F. Detail of styles showing twisted papillose stigmas. G. Cross section of an immature fruit. H. Immature fruit (side view). I. Detail of a stipule. A \& B from P. Azlan et al. BRUN 23373, C-J from ex-situ collection at BRUN. (Photos: A \& B, A.K. Muhammad Ariffin; C-J, Y.W. Low) 


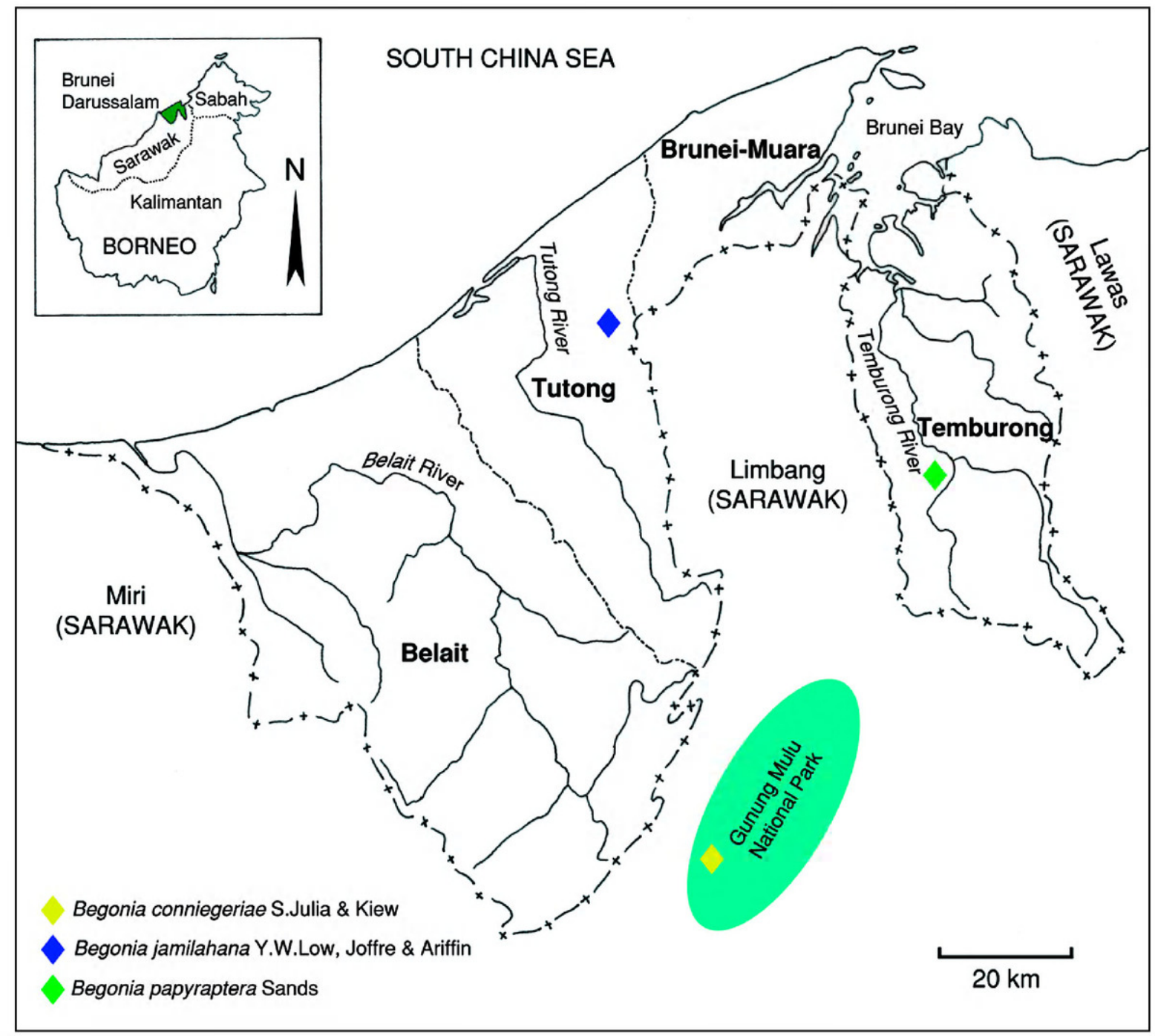

Fig. 2. Distribution of Begonia conniegeriae S.Julia \& Kiew, Begonia jamilahana Y.W.Low, Joffre \& Ariffin, and Begonia papyraptera Sands.

Temburong district (Johns et al. RJ7422), without a detailed description but with a brief Latin diagnosis as follows:

“a $B$. congesta Ridley alis fructus latioribus, caulibus plusminusve glabris (non 'hirtis'), staminibus 15 vel plus (non 12), tepalis staminibus multo longioribus (non brevioribus); a $B$. leucochlora (vide supra) fructus apice rotundato (non alis acutis et fructus apice truncato), petiolis longioribus differt."

A total of three duplicates were gathered, with two sheets indicated as holotype in K (Sheet 1 of 2: K000761105, and Sheet 2 of 2: K000761106); while the third sheet, which is an isotype, is lodged in BRUN (herbaria acronyms follow Thiers, continuously updated). For this study, the two holotype sheets were examined through the Southeast 
Asian Begonia database (Hughes \& Pullan, 2007), as well as the JSTOR ${ }^{\mathbb{R}}$ Global Plants website (Global Plants, continuously updated). Detailed examination was carried out on the isotype preserved in BRUN. In addition, a living plant of Begonia papyraptera was discovered recently by the second author in cultivation in the ex-situ collection of begonias at the Kuala Belalong Field Study Centre (KBFSC). This cultivated specimen in KBFSC matches the type materials represented in $\mathrm{K}$ and BRUN and, therefore, provided us with further insights into the species for this study.

Begonia conniegeriae S.Julia \& Kiew was described in Sang et al. (2013). We have been unable to examine the materials as the isotype indicated in the article as having been distributed to SING had not arrived by 13 March 2015 (Serena Lee (SING), pers. comm.). Images of the type materials were also not available for examination either in the Southeast Asian Begonia database (Hughes \& Pullan, 2007) or the JSTOR ${ }^{\mathbb{E}}$ Global Plants website (Global Plants, continuously updated). The morphological characters of Begonia conniegeriae used in this study are extracted from Sang et al. (2013).

ACKNOWLEDGEMENTS. We are grateful to Haji Saidin bin Salleh, the Director of Forestry Department, Brunei Darussalam for providing us with field support and assistance for this study. Special thanks to Hajah Jamilah binti Haji Abdul Jalil and Noralinda binti Haji Ibrahim for their encouragement and continuous support and assistance. Dr Ruth Kiew (KEP) kindly made available translated Latin diagnoses by Dr Mark Coode (K) of all the Begonia species described by Martin Sands (K) published in Coode et al. (1996) for this study. Various staff members of the Brunei National Herbarium (BRUN) have kindly helped: Mediana Kampong and Muhd. Wafiuddin Zainol Ariffin assisted with herbarium materials and database; Watu Awok, Azlan Pandai, Jangarun Eri and Rauzaidi Mureh provided excellent assistance in the field, as well as maintaining the ex-situ research collection. Research funding for YWL is provided by the National Parks Board, Singapore and the Singapore Botanic Gardens. Christina Soh (Library of Botany and Horticulture, Singapore Botanic Gardens) kindly helped with missing references. We are grateful to the two reviewers, Dr Mark Hughes (E) and Dr Daniel C. Thomas (SING), for their constructive comments in improving this manuscript. This research collaboration is conducted under the MoU programme "The Botanical Survey of Brunei Darussalam" between the Brunei Forestry Department, Ministry of Industry and Primary Resources and the National Parks Board, Singapore.

\section{References}

Brunei Times (2014). Logging no longer allowed in forest reserves: Ministry of Industry and Primary Resources. 23 March 2014. http://bt.com.bn/news-national/2014/03/23/ logging-no-longer-allowed-forest-reserves-mipr (accessed on 13 Feb. 2015).

Coode, M.J.E., Dransfield, J., Forman, L.L., Kirkup, D.W. \& Said, I.M. (1996). A Checklist of the Flowering Plants and Gymnosperms of Brunei Darussalam. xvii +477 p. Brunei Darussalam: Ministry of Industry and Primary Resources. (Begoniaceae, p. 38-41)

Doorenbos, J., Sosef, M.S.M. \& de Wilde, J.J.F.E. (1998). The Sections of Begonia: including descriptions, keys and species lists. 266 p. The Netherlands: Wageningen Agricultural University. 
Global Plants (continuously updated). JSTOR® Global Plants. ITHAKA. http://plants.jstor. org/ (accessed on 13 Mar. 2015).

Heywood, V.H., Brummitt, R.K., Culham, A. \& Seberg, O. (2007). Flowering Plant Families of the World. 424 p. UK: Royal Botanic Gardens, Kew. (Begoniaceae, p. 58-59)

Holttum, R.E. \& Enoch, I. (1995). Gardening in the Tropics. viii + 384 p. Singapore: Times Edition.

Hughes, M. (2008). An Annotated Checklist of Southeast Asian Begonia. xi + 164 p. UK: Royal Botanic Garden Edinburgh.

Hughes, M. \& Pullan, M. (2007). Southeast Asian Begonia Database. Royal Botanic Garden Edinburgh. http://elmer.rbge.org.uk/Begonia/ (accessed on 10 Dec. 2014).

Merrill, E.D. (1921). A bibliographic enumeration of Bornean plants. J. Straits Branch Roy. Asiat. Soc. Special No. Singapore: Fraser \& Neave Ltd. (Begoniaceae, p. 414-416)

Sands, M.J.S. (1996). Begoniaceae: Begonia. In: Coode, M.J.E., Dransfield, J., Forman, L.L., Kirkup, D.W. \& Said, I.M. (eds) A Checklist of the Flowering Plants and Gymnosperms of Brunei Darussalam. Brunei Darussalam: Ministry of Industry and Primary Resources. (Begoniaceae, p. 38-41)

Sang, J., Kiew, R. \& Geri, C. (2013). Revision of Begonia (Begoniaceae) from the Melinau limestone in Gunung Mulu National Park and Gunung Buda National Park, Sarawak, Borneo, including thirteen new species. Phytotaxa 99(1): 1-34.

Tebbit, M.C. (2005), Begonias: Cultivation, Identification and Natural History. 272 p. Portland: Timber Press.

Thiers, B. (continuously updated). Index Herbariorum: A global directory of public herbaria and associated staff, New York Botanical Garden's Virtual Herbarium. http://sweetgum. nybg.org/ih/ (accessed on 6 Mar. 2015). 


\section{$2 \mathrm{BHL}$ Biodiversity Heritage Library}

Low, Y. W., Joffre, A A, and Ariffin, A K Muhammad. 2015. "Novitates

Bruneienses, 2. A remarkable new species of Begonia sect. Petermannia (Begoniaceae) from Brunei Darussalam." The Gardens' bulletin, Singapore 67(1), 61-68. https://doi.org/10.3850/s2382581215000071.

View This Item Online: https://www.biodiversitylibrary.org/item/223283

DOI: https://doi.org/10.3850/s2382581215000071

Permalink: https://www.biodiversitylibrary.org/partpdf/229505

\section{Holding Institution}

Singapore Botanic Gardens, National Parks Board Singapore

\section{Copyright \& Reuse}

Copyright Status: In copyright. Digitized with the permission of the rights holder.

License: http://creativecommons.org/licenses/by-nc-sa/4.0/

Rights: https://biodiversitylibrary.org/permissions

This document was created from content at the Biodiversity Heritage Library, the world's largest open access digital library for biodiversity literature and archives. Visit BHL at https://www.biodiversitylibrary.org. 